TITLE:

\title{
FIVE CARIDEAN SHRIMPS ASSOCIATED WITH SEA ANEMONES IN CENTRAL JAPAN
}

$\operatorname{AUTHOR}(S)$ :

Suzuki, Katsumi; Hayashi, Ken-ichi

\section{CITATION:}

Suzuki, Katsumi ... [et al]. FIVE CARIDEAN SHRIMPS ASSOCIATED WITH SEA ANEMONES IN CENTRAL JAPAN. PUBLICATIONS OF THE SETO MARINE BIOLOGICAL LABORATORY 1977 , 24(1-3): 193-208

ISSUE DATE:

1977-11-30

URL:

http://hdl.handle.net/2433/175952

RIGHT: 


\title{
FIVE GARIDEAN SHRIMPS ASSOGIATED WITH SEA ANEMONES IN GENTRAL JAPAN ${ }^{1,2}$
}

\author{
KATSUMI SUZUKI \\ Marine Science Museum, Tokai University, Shimizu, Japan \\ and \\ KEN-IGHI HAYASHI \\ Shimonoseki University of Fisheries, Yoshimi, Shimonoseki, Japan
}

With Text-figures $1-5$ and Plates $1-I I$

The senior author has been studying the littoral fauna of Uchiura coast, the inner part of Suruga Bay $\left(35^{\circ} 02^{\prime} \mathrm{N}, 138^{\circ} 53^{\prime} \mathrm{E}\right)$, and for the last three years has examined the relationship between sea anemones and caridean shrimps chiefly based upon observations by personal SCUBA diving, as well as upon the laboratory rearing at the Marine Science Museum, Tokai University (Fig. 1). The junior author collected crustacean decapods at Kushimoto, southernmost point of the Kii Peninsula $\left(33^{\circ} 28^{\prime} \mathrm{N}\right.$, $135^{\circ} 44^{\prime} \mathrm{E}$ ), from 1970 to 1973 and has collected many decapods from various invertebrate hosts. Both authors pooled their data on the shrimps associated with sea anemones. The following five shrimps proved to be associated with sea anemones in both localities.

Family Hippolytidae

Thor amboinensis (De Man)

Family Palaemonidae

Hamopontonia corallicola Bruce

Periclimenes brevicarpalis (Schenkel)

Periclimenes holthuisi Bruce

Periclimenes ornatus Bruce

The present paper contains brief taxonomic notes on these shrimps and ecological notes on the symbiotic relationships between the shrimps and their host anemones. The shrimps reach the northernmost point of their distributions and two of them, $H$. corallicola and $P$. ornatus, are new to the Japanese fauna. The former is a new symbiont with sea anemones. The precise relationships between the shrimps and sea anemones vary in different species. $H$. corallicola, $P$. brevicarpalis and $P$. ornatus depend obligately upon sea anemones and associate with their hosts for shelter and a

1) Contributions from the Marine Science Museum, Tokai University, No, 43.

2) Contribution from the Shimonoseki University of Fisheries, No. 819.

Publ. Seto Mar. Biol. Lab., XXIV (1/3), 193--208, 1977

(Article 15) 


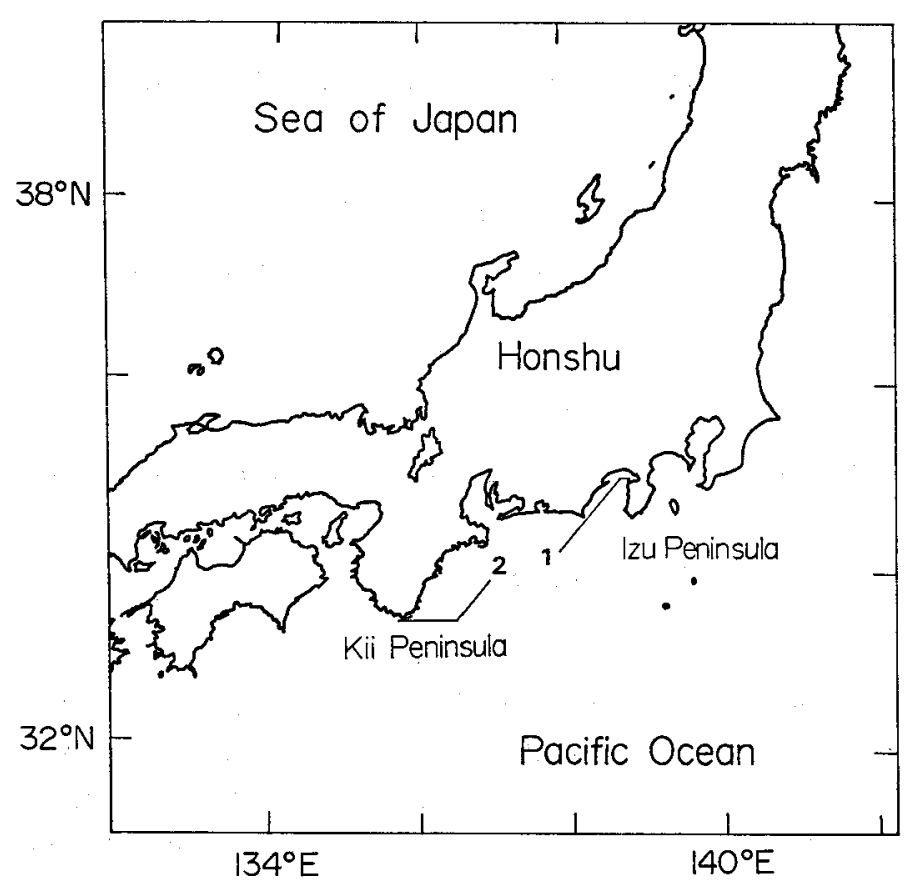

Fig. 1. Map showing the stations where the observations were made. 1, Uchiura coast (Suruga Bay); 2, Kushimoto.

part of their food. Their relationships are considered to be parasitic rather than commensal. T. amboinensis does not have a close relationship with sea anemones and can be reared for long time in isolation. $P$. holthuisi needs sea anemones or anemonelike corals but is thought to have a rather loose relationship with its respective hosts.

$H$. corallicola and $P$. ornatus probably pass through their whole life in central Japan and the other three species may be carried from southern waters by the Kuroshio Current.

\section{Materials and Methods}

Field observations of sea anemones and the associated shrimps have carried out at Suruga Bay on the Uchiura coast, during eight months from May 1974 to January 197.5 by the senior author and his colleagues. Before and after this period they researched many times in the coast and confirmed the presence of the shrimp-anemone associations. Based upon the preliminary research prior to May 1974, two stations were established. One of them was located near the town of Kuryo, inner side of the so-called "Uchiura Bay". Two rope lines $100 \mathrm{~m}$ long were set parallel to each other from the tidal line at intervals of $2 \mathrm{~m}$. Along either side of these two rope-lines, associated shrimps were examined twice or more in each month, and some of them were collected for laboratory research. On the other hand another station of about $100 \mathrm{~m}^{2}$ was selected near the entrance of "Uchiura Bay", which was a center of a luxuriant 
growth of sea anemones. In the latter station the shrimps were usually counted and a great number of specimens were collected and preserved on 12th November 1974. An area between these two stations was several times researched and the shrimps collected from there were used for laboratory rearing and for taxonomical studies. Field or laboratory observations on these shrimps were also made at Kushimoto, where the shrimps were collected occasionally and some of them were also preserved for taxonomical studies and the remaining ones were reared in an aquarium of the Kushimoto Marine Park.

Underwater observations were recorded on a plastic notebook and they were partly supplemented by underwater photographs. The shrimps were examined alive by binocular microscope and were photographed in natural colour. After fixation in $10 \%$ formalin, they were measured and examined in detail.

\section{Systematics of associated shrimps}

Thor amboinensis (De Man)

(Figs. 1a and 2a)

Japanese name: Isoginchaku moebi (Hirata et al, 1973)

Hippolyte amboinensis De Man, 1888, p. 535.

Thor amboinensis Holthuis, 1947, pp. 14, 50 (synonymy); Chace, 1972, p. 130, figs. 55, 56; Hirata, Nakasone, Shokita, 1973, p. 57, with colour fig.; Bruce, 1975, p. 27, fig. 14 (colour); Miyake, 1975, two colour figs. on pp. 20 and 102.

Remarks: This hippolytid shrimp is readily distinguished from the other four palaemonids by the short rostrum, not reaching end of eye, slender second pereiopod with carpus subdivided into six joints and the unique colour pattern, "a dark olive brown body with numerous large round white opalescent patches" (Bruce, 1975).

Size: The specimens ( 1 ô, 2웅) are examined. The male is $1.5 \mathrm{~mm}$ and two females are 1.9 and $2.5 \mathrm{~mm}$ in postorbital carapace length.

Distribution: It shows the circumtropical distribution (Chace, 1972). In Japan: Ishigaki-jima Island (Miyake and Hayashi, 1966); Okinawa (Hirata et al, 1973), Yoronto Island, Amami Islands (Hayashi, private observation), Izu Peninsula and southern part of Kii Peninsula (Miyake, 1975).

\section{Hamopontonia corallicola Bruce}

(Figs. $1 \mathrm{~b}$ and 2b, Pl. 1)

New Japanese name: Hime isoginchakuebi

Hamopontonia corallicola Bruce, 1970, p. 41, figs. 1-4.

Remarks: The genus Hamopontonia is characterized by a forked telson and contains a single species, $H$. corallicola. The forked telson is a unique character, not only in 
the subfamily Pontoniinae of Palaemonidae, but also in the section Caridea.

The present specimens examined ( $2 \delta^{\star} \delta^{\star}, 2$ ovig. 우우, 2 우우) agree well with the original description of this species, except for a lack of the outer spine of the first antennular peduncle in two specimens and for three or four pairs of dorsal spines on the telson in all specimens. H. corallicola is distinguished from the following three species of Periclimenes by the absence of the hepatic spine and of teeth on the lower margin of the rostrum as well as the forked telson.

The colouration of ovigerous females is well described by Bruce (1970). In males the body is largely transparent with a large, transverse white patch on the gastric region. The abdomen is largely transparent. The pereiopods are similar to those of females.

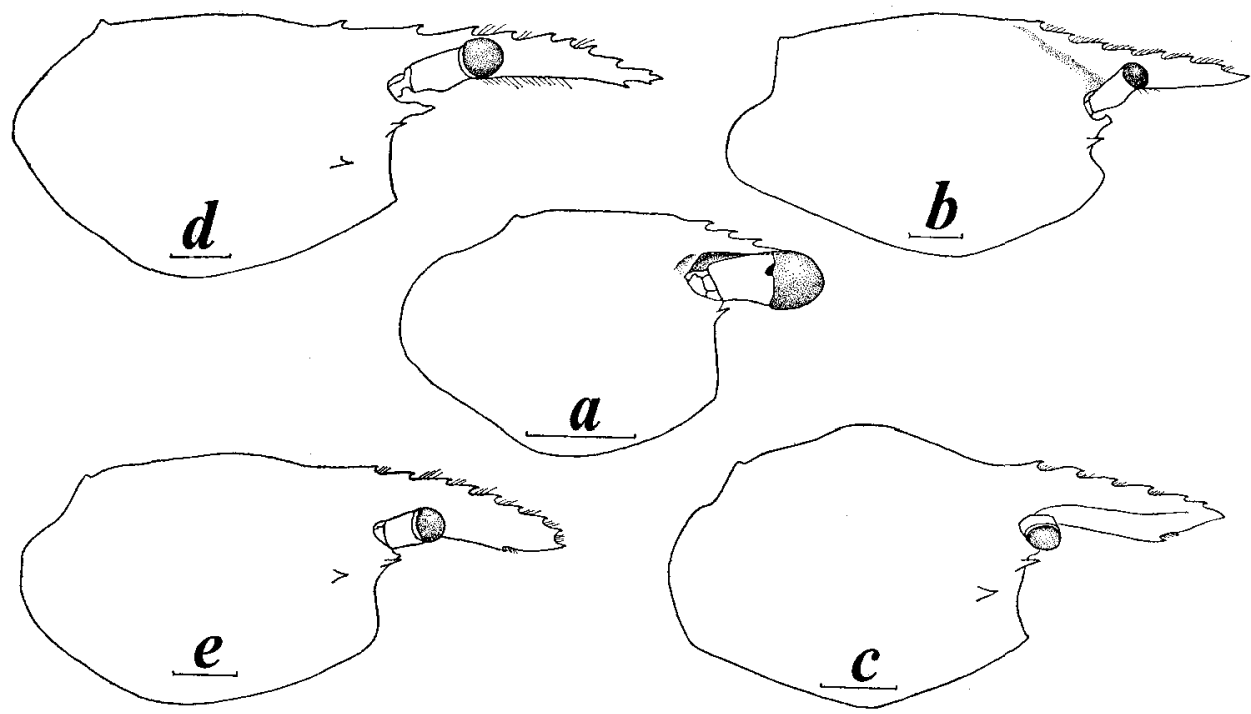

Fig. 2. Carapace of five shrimps associated with sea anemones; $a$, female of Thor amboinensis (De Man), $b$, ovigerous female of Hamopontonia corallicola Bruce, $c$, female of Periclimenes brevicarpalis (Schenkel), $d$, female of Periclimenes holthuisi Bruce, $e$, ovigerous female of Periclimenes ornatus Bruce. Scale for $a, b, e$ represent $1.0 \mathrm{~mm}$ and those for $c, d$ represent $1.5 \mathrm{~mm}$.

Size: The ovigerous females vary from 4.2 to $5.1 \mathrm{~mm}$ and the largest male is $3.0 \mathrm{~mm}$ in carapace length.

Distribution: The species has been recorded only from the type locality, Hong Kong (Bruce, 1970).

\section{Periclimenes brevicarpalis (Schenkel)}

(Figs. 1c and 2c, Pl. 2 fig. 1)

Japanese name: Isoginchaku ebi (Hirata et al, 1973)

Ançvlocaris brevicarpalis Schenkel, 1902, p. 563, pl. 13 fig. 21.

Preiclimenes (Ancylocaris) brevicarpalis Kubo, 1940, p. 46, figs. 13, 14. 
Periclimenes (Harpilius) brevicarpalis Holthuis, 1952, pp. 10, 69, fig. 27 (synonymy); Suzuki, Kobayashi, Abe and Fukuda, 1972, p. 9.

Periclimenes brevicarpalis Hirata, Nakasone, Shokita, 1973, p. 56 with colour fig.

Remarks: This species is the most famous symbiont with sea anemones and characterized by the simple dactyli of the last three pereiopods, two pairs of dorsal spines placed near distal part of the telson and the gastric region largely swollen in the ovigerous females. The colour pattern is well described by Kemp (1922) and beautifully photographed by Hirata et al (1973). It is diagnostic that "in the latter half of the telson of each uropod there was a brilliant eyespot" (Kemp, 1922).

Size: Five specimens examined (4 ovig. 우우 1 ㅇ); ; the ovigerous females vary from 5.2 to $7.0 \mathrm{~mm}$ in carapace length.

Distribution: This species has been recorded throughout the Indo-West Pacific region (Miyake and Fujino, 1968). In Japan: Ishigaki-jima Island (Kubo, 1940); Okinawa (Hirata et al, 1973); Izu Peninsula (Suzuki et al, 1972).

\section{Periclimenes holthuisi Bruce}

(Figs. 1d and 2d)

Japanese name: Akahoshi kakureebi (Miyake, 1975)

Periclimenes (Periclimenes) aesopius Holthuis, 1952, pp. 8, 34, figs. 5, 6 (not Anchistus aesopia Bate).

Periclimenes holthuisi Bruce, 1969, p. 258; Monod, 1969, p. 216, figs. 69-73; Bruce, 1972, p. 300; Miyake, 1975, colour fig. on p. 103.

Remarks: This species is characterized by the humped third abdominal somite, the elongated suborbital angle and the bifurcated dactyli of the last three pereiopods. The colour pattern is described by Bruce (1969 and 1972) and Monod (1969), and photographed in colour by Miyake (1975).

Size: Six specimens examined $\left(3 \hat{\partial} \sigma^{\star}, 3\right.$ q 9 ) vary from 2.7 to $7.0 \mathrm{~mm}$ in carapace length.

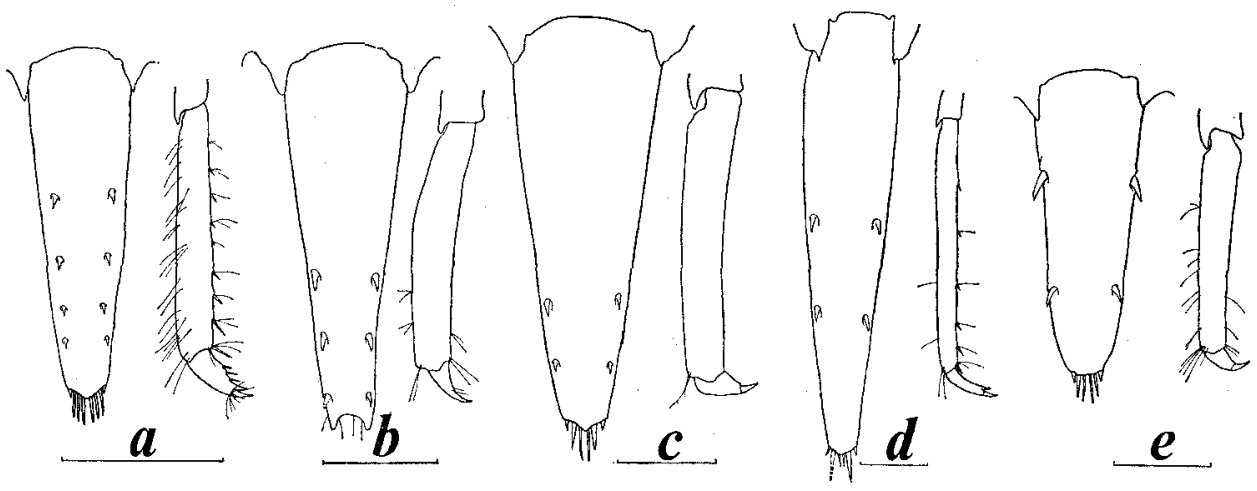

Fig. 3. Telson and two distal segments of the third pereiopod of the same individuals shown in the Fig. 1; $a$, Thor amboinensis (De Man), b, Hamopontonia corallicola Bruce, c, Periclimenes brevicarpalis (Schenkel), d, Periclimenes holthuisi Bruce, e, Periclimenes ornatus Bruce. Scales represent $1.0 \mathrm{~mm}$. 
Distribution: Maldive, Ceylon, Moluccas, Hong Kong, South China Sea, Japan, New Caledonia, Queensland (Bruce, 1969), Zanzibar harbour (Bruce, 1972). In Japan: Ishigaki-jima Island (Fukuda, private observation), Amakusa Islands, Nagasaki and Miura Peninsula (Miyake, 1975).

\section{Periclimenes ornatus Bruce}

(Figs. 1e and 2e, Pl. 2 fig. 2)

New Japanese name: Kazari isoginchakuebi

Periclimenes ornatus Bruce, 1969, p. 266.

Remarks: This species is related to $P$. brevicarpalis and $P$. inornatus, both of which were collected from sea anemones, in having the simple dactyli of the last three pereiopods. $P$. ornatus is distinguished from $P$. brevicarpalis by the dorsal spines on the telson situated equidistantly and from $P$. inornatus by the longer fingers of the second pereiopod and the colour pattern as mentioned by Bruce (1969 and personal communication).

The animal is entirely transparent, with two red, narrow longitudinal and one white longitudinal lines on either side of the body. Appendages including uropods are dotted by purple and white spots. The colour pattern does not show apparent sexual differences.

Size: Nine specimens examined (4 숭, 1 ovig. 우, 3 웅, $1 \mathrm{sp}$.) are $2.8-5.2 \mathrm{~mm}$ in carapace length.

Distribution: The species is reported only from Hong Kong (Bruce, 1969).

\section{Relationship between shrimps and sea anemones}

Host sea anemones: According to Dr. Uchida, the following four sea anemones, from which the associated shrimps were collected, are observed on the Uchiura coast, Parasicyonis actinostroides (Wassilieff), P. maxima (Wassilieff), Radianthus maculata (Klunzinger) and Dofleinia armata (Wassilieff). Six large sea anemones have been found in the seas near Kushimoto (Uchida et al, 1975) and three of them, the two species of Parasicyonis and Stoichactis haddoni (Saville-Kent), are observed to be the natural hosts of the shrimps.

Except for Dofleinia armata, the other four sea anemones fix their pedal disk on rocks or dead corals at the depths varying from 1.5 to $20 \mathrm{~m}$. Dofleinia armata, on the other hand, is embedded in muddy sand bottom at the depths of $20-40 \mathrm{~m}$. On the Uchiura coast, Parasicyonis actinostroides is the most dominant species and the two species of Parasicyonis are codominant in Kushimoto area, too. P. actinostroides occurs in more shallow waters than does P. maxima.

Occurrence of shrimps: The occurrence of the associated shrimps on the Uchiura coast from May 1974 to January 1975 is shown in the Fig. 4. H. corallicola is first 
observed in association with Parasicyonis actinostroides in early May. Subsequently $P$. holthuisi appears in late May. P. brevicarpalis is first discovered on $P$. actinostroides in early July, and $T$. amboinensis and $P$. ornatus are first found on the same anemone in carly August. In 1976 P. ornatus already appears in April and May.

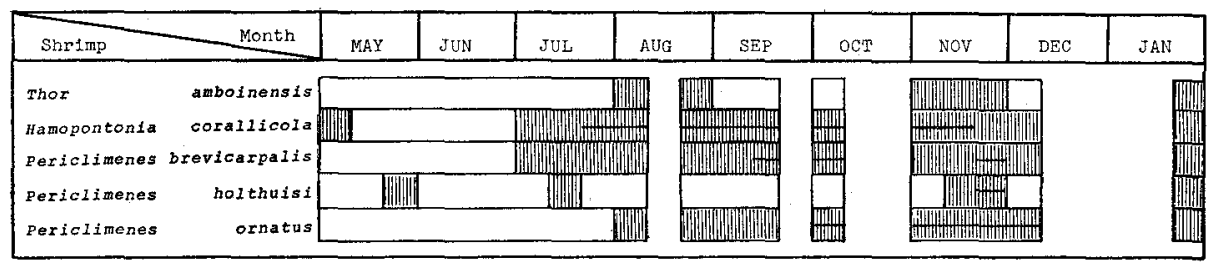

Fig. 4. Occurrence of five shrimps associated with sea anemones in Suruga Bay during May 1974January 1975. The period stadied is encircled by thin line. The shaded area is the period, in which some specimens were obtained or observed. The bar shows the presence of the ovigerous female.

During the research period from May 1974 to January 1975, the ovigerous females appear continuously from late July to middle November in $H$. corallicola and from early October to early December in $P$. ornatus, whenever the research is carried out. The ovigerous females of $P$. brevicarpalis appear in middle September, early October and middle November. $P$. holthuisi is rare and its ovigerous female is observed in late November only and those of $T$. amboinensis are not found in this area. After this period, the ovigerous females of $H$. corallicola are found in late June and late January, and those of $P$. ornatus are also collected in late June and late October. There is no additional data on the ovigerous seasons of $T$. amboinensis and $P$. holthuisi.

The specimens observed in Sation 2 on 12th November 1974 were all captured in order to examine the species composition of the associated shrimps. The host anemones occured in this station are composed of a single species, Parasicyonis actinostroides and counted 1404 in total in $100 \mathrm{~m}^{2}$ researching area. The species composition of the captured shrimps is shown in the Table 1. The pontoniine shrimp, $P$. ornatus, forms more than three-quarters of the total catch, and $P$. holthuisi was not collected at all.

Table 1. The species composition of the shrimps associated with sea anemones obtained from station 2 on the Uchiura coast, Suruga Bay

\begin{tabular}{lcc}
\hline \multicolumn{1}{c}{ Species } & No. of individuals & Percentage (\%) \\
\hline Thor amboinensis & 9 & 10.2 \\
Hamopontonia corallicola & 4 & 4.5 \\
Periclimenes brevicarpalis & 8 & 9.1 \\
Periclimenes holthuisi & 0 & 0 \\
Periclimenes ornatus & 67 & 76.2 \\
Total & 88 & 100.0 \\
\hline
\end{tabular}


Partnership between shrimps and sea anemones: The partnership between the shrimps and the sea anemones observed in Uchiura coast and seas near Kushimoto is shown in the Table 2.

A host sea anemone houses usually only one specimen in the case of $P$. holthuisi. Two specimens are mostly collected from a single host in $H$. corallicola and two or more specimens are observed in $P$. brevicarpalis, $P$. ornatus and $T$. amboinensis. If two specimens are collected from a single host, usually they are a male-female pair in $H$. corallicola and $P$. brevicarpalis. The latter species is sometimes collected together with either the former species or $P$. ornatus on an individual of Parasicyonis actinostroides and in another case $H$. corallicola and $P$. ornatus are observed together with each other on one host.

Table 2. The partnerships between the shrimps and the sea anemones under natural conditions on the Uchiura coast (solid line) and at Kushimoto (dotted line)

Shor amboinensis
$\begin{aligned} & \text { Samopontonia corallicola } \\ & \text { Periclimenes brevicarpalis } \\ & \text { Periclimenes holthuisi } \\ & \text { Periclimenes }\end{aligned}$ ornatus

Laboratory rearing: The laboratory rearing of the shrimps and the sea anemones reveals some facts concerning the interspecific relationships between them. At the Tokai University $P$. holthuisi recently separated from Dofleinia armata in the sea and $P$. ornatus from Parasicyonis actinostroides are both eaten by $D$. armata, which has been reared in a small aquarium for long period, as soon as the shrimps just touch a tentacle of the anemone. On the other hand, $P$. holthuis $i$ just obtained from $D$. armata is not seized by the tentacles of similarly reared Parasicyonis maxima, while $P$. brevicarpalis from Parasicyonis actinostroides immediately land on oral disk of another individual of that species that has been rearing for long term. An isolated Parasicyonis actinostroides is capable to simultaneously accommodate the four species of the shrimps, $H$. corallicola, $P$. brevicarpalis, $P$. ornatus and $T$. amboinensis, which are successively added to the aquarium. These four shrimps live separately on oral disk or trunk of this anemone and were seen not to attack to one another during observations.

In Kushimoto a single specimen of $P$. holthuisi, whose host was uncertain under natural condition, can live in the following four different sea anemones, Stoichactis haddoni, Cryptodendrum adhesivum, Heterodactyla hemprichii and Megalactis griffithsi, which were occasionally collected from the coast of Kushimoto and reared together with the shrimp in the same aquarium. Stoichactis haddoni seems to be the most suitable host for this shrimp, because it is usually found in association with this anemone. $P$. ornatus, which was collected from either of the two species of Parasicyonis under seas, is immediately able to establish the partnership with Cryptodendrum adhesioum reared in isolation in aquarium. 


\section{Discussion}

It is not necessary to discuss these five associated shrimps taxonomically. Including the present data, the shrimp-anemone associations from the Indo-West Pacific region are summarized in the Table 3. Periclimenes inornatus Kemp has not been found from Japan during the present study. It is closely related to $P$. ornatus in its general morphology and ecology. As mentioned by Bruce (1971) P. ornatus is distinguished from $P$. inornatus by the colour pattern and by the shape of the chelae of the second pereiopod. Except for $H$. corallicola, of which the present report is the second record of the species, the remaining three species are known throughout the vast Indo-West Pacific region.

There is not any definite specific relationship between the shrimps and sea anemones (Table 3). T. amboinensis was reported in association with other coelenterates than sea anemones; such as the scleractinian corals, Pocillopora, Stylophora (Patton, 1966) and Acropora (Hayashi, private observation) and the stinging polyp, Stephanoscyphus racemosus (Miyake, 1975). When this hippolytid shrimp is associated with sea anemones, it is usually found below the flattened oral disk or on a trunk of the cylindrical type of sea anemones, and seldom seen on the oral disk. Moreover it rather easily separates from the host anemones, when touched or disturbed by divers. This shrimp can be reared for long period free from sea anemones in an aquarium. Hirata et al (1973) mentioned 2-50 individuals were collected from a single host.

H. corallicola was originally reported from the scleractinian coral, Goniopora stokesi, and $P$. holthuisi occures on another coral, Euphyllia fimbriata in Ishigaki-jima Island (Fukuda, personal communication). Although these two shrimps are observed on the tentacles of the scleractinian corals, they can not be considered similar to the case of $T$. amboinensis. The general appearance of these two corals is very different from that of Pocillopora and Acropora and looks somewhat like sea anemones, as they have a long coenosarc or tentacles in each polyp and extend far enough to conceal the shrimps in them during the daytime. $P$. holthuisi was collected from the scyphozoan medusae, Cassiopea andromeda, at Zanzibar harbour (Bruce, 1972). This jellyfish also closely resembles sea anemones in general appearance.

On the Uchiura coast, $P$. holthuisi is usually observed on the tentacles or oral disk of the host anemone. When the divers get near the host anemone, this shrimp removes for short distance from the host and then swings his body and large second pereiopods there. Holthuis and Eibl-Eibesfeldt (1964) reported this swaying motions of the Atlantic anemone shrimp, Periclimenes anthophilus and very recently also observed similar phenomenon in $P$. brevicarpalis and T. amboinensis, too (Bruce, 1976). If the divers attempt to catch $P$. holthuisi, it returns to the anemone in order to hide itself between tentacles of the host, and finally departs from the host again, but always remains near the host. $P$. holthuisi can live on six different sea anemones in an aquarium in Kushimoto and is collected from three anemones under natural condition of Suruga Bay.

$P$. brevicarpalis and $P$. ornatus, as well as $H$. corallicola never move from their 
Table 3. The shrimp-sea anemone associations from the Indo-West Pacific region

\begin{tabular}{|c|c|c|c|}
\hline Associated shrimp & Host Sea-anemone & Author & Locality \\
\hline \multirow[t]{6}{*}{ Thor amboinensis } & Parasicyonis actinostroides & Present study & Honshu, Japan \\
\hline & Radianthus maculata & Present study & Honshu, Japan \\
\hline & Stoichactis haddoni & Present study & Honshu, Japan \\
\hline & Stoichactis kenti & Miyake \& Hayashi, 1966 & Ishigakijima I. \\
\hline & & Hirata, Nakasone \& & \\
\hline & & Shokita, 1973 & Okinawa \\
\hline \multirow{2}{*}{ Hamopontonia corallicola } & Parasicyonis actinostroides & Present study & Honshu, Japan \\
\hline & Parasicyonis maxima & Present study & Honshu, Japan \\
\hline \multirow[t]{22}{*}{ Periclimenes brevicarpalis } & Actiniaria & Johnson, 1960 & Singapore \\
\hline & Parasicyonis actinostroides & Suzuki, Kobayashi, Abe & \\
\hline & & \& Fukuda, 1972 & Honshu, Japan \\
\hline & & Present study & Honshu, Japan \\
\hline & Parasicyonis maxima & Present study & Honshu, Japan \\
\hline & Radianthus ritteri & Bruce, 1971 & Seychelles \\
\hline & Radianthus maculata & Present study & Honshu, Japan \\
\hline & Stoichactis giganteum & Coutière, 1898 & Jibuti \\
\hline & & Nobili, 1906 & Jubuti \\
\hline & & Gravely, 1927 & Gulf of Manaar \\
\hline & & Nayer, 1947 & Gulf of Manaar \\
\hline & Stoichactis haddoni & Saville-Kent, 1893 & G.B.R., Australia \\
\hline & Stoichactis kenti & $\begin{array}{l}\text { Stephenson, Stephenson, } \\
\text { Tandy \& Spender, } 1931\end{array}$ & G.B.R., Australia \\
\hline & & Kubo, 1940 & Ishigakijima I. \\
\hline & & Miyake \& Fujino, 1968 & Palau Is. \\
\hline & Stoichactis sp. & Kemp, 1916 & Andaman Is. \\
\hline & & Borradaile, 1917 & Torres Strait \\
\hline & & Kemp, 1922 & Andaman Is. \\
\hline & & McCulloch \& McNeil, & \\
\hline & & 1923 & G.B.R., Australia \\
\hline & & Barnard, 1950 & Delagoa Bay \\
\hline & Thalassianthus hypnoides & $\begin{array}{l}\text { Stephenson, Stephenson, } \\
\text { Tandy \& Spender, } 1931\end{array}$ & G.B.R., Australia \\
\hline \multirow[t]{4}{*}{ Periclimenes holthuisi } & Actiniaria & Bruce, 1969 & Hong Kong \\
\hline & Dofleinia armata & Present study & Honshu, Japan \\
\hline & Parasicyonis actinostroides & Present study & Honshu, Japan \\
\hline & Radianthus maculata & Present study & Honshu, Japan \\
\hline \multirow[t]{3}{*}{ Periclimenes inornatus } & Radianthus ritteri & Bruce, 1971 & $\begin{array}{l}\text { Comoro Is. } \\
\text { Seychelles }\end{array}$ \\
\hline & & Bruce, $1976 a$ & Seychelles \\
\hline & Stoichactis sp. & Kemp, 1922 & Andaman Is. \\
\hline \multirow[t]{3}{*}{ Periclimenes ornatus } & Actiniaria & Bruce, 1969 & Hong Kong \\
\hline & Parasicyonis actinostroides & Present study & Honshu, Japan \\
\hline & Parasicyonis maxima & Present study & Honshu, Japan \\
\hline
\end{tabular}


hosts, even with persistent disturbances. If the host sea anemone retracts entirely, the shrimps are always missing. It is observed in the field that these three species tear off tentacles of the host by their chelae, probably for food. This fact is confirmed by a laboratory rearing. The stomach of $H$. corallicola and $P$. ornatus contains many nematocysts of sea anemones and their symbiotic algae, Zooxanthellae (Fig. 5). While $P$. brevicarpalis picks up youngs of a rhynchocinetid shrimp, which are food for the host in a laboratory. It probably shows the shrimp snatches the prey of sea anemones. The relationships between these three shrimps and the host sea anemones are

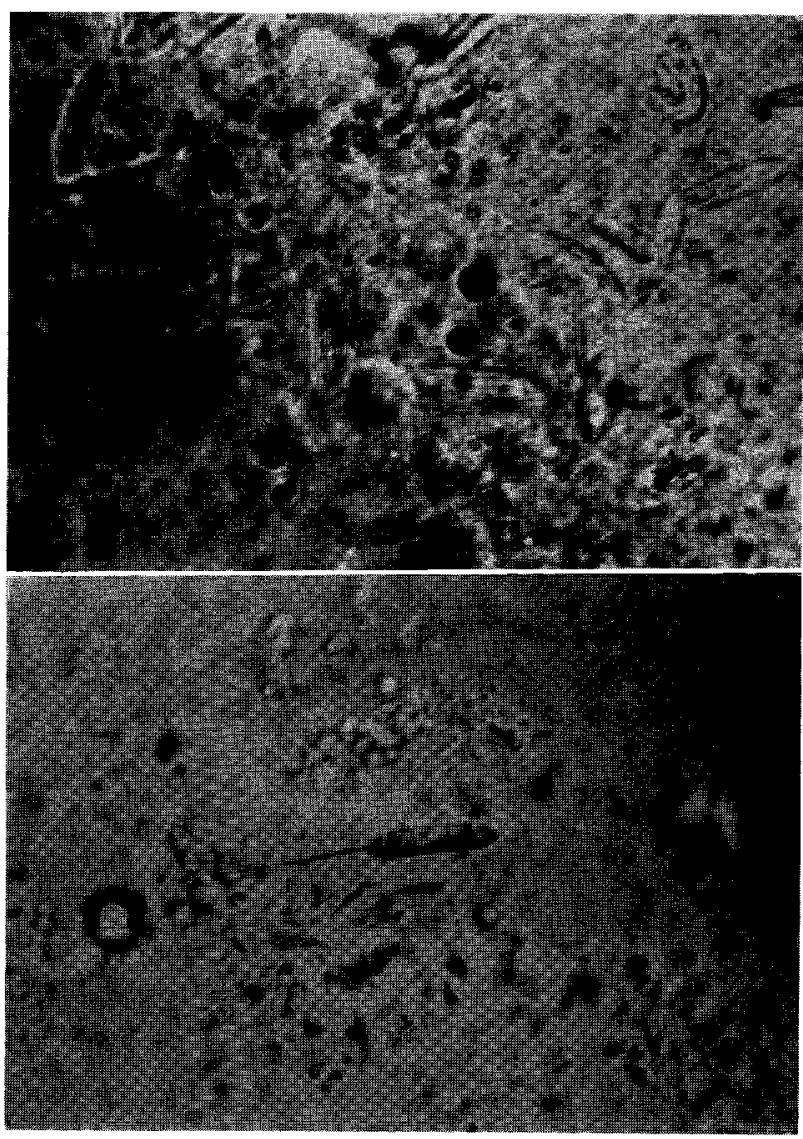

Fig. 5. Stomach contents of Hamopontonia corallicola Bruce associated with Parasicyonis actinostroides (Wassilieff) in an aquarium, showing nematocysts and symbiotic algae, Zooxanthella, of the host.

thought to be parasitic rather than commensal, although the heavy damage, which is known in the host sea urchins parasited by the small crab, Zebrida adamsii (Suzuki and Takeda, 1974), can not be observed.

These facts indicate that $H$. corallicola, $P$. brevicarpalis and $P$. ornatus depend obligately upon sea anemones. They always live on the host, using it as shelter and getting from it a part of their food. $P$. holthuisi is rather loose association with the re- 
spective sea anemone but it seems not to live without sea anemones or anemone like corals. The function of its striking colour pattern accompanying the swaying movements is not still obscure. As discussed by Bruce (1976), it may be linked to the cleaning behavior (Limbaugh, Pederson and Chace, 1961; Mahnken, 1972), but actual cleaning by $P$. holthuisi could not be observed in natural nor aquarium conditions. T. amboinensis associates with sea anemones for shelter, but their relationship is rather loose.

$P$. ornatus and $H$. corallicola have been only known from the West Pacific and their hosts are mostly the two species of Parasicyonis. P. brevicarpalis has been reported in association with the species of Stoichactis in the tropical waters, which are the distributional center for this shrimp. Although it was collected from Radianthus ritteri in Seychelles, no anemones of the genus Stoichactis were observed at the collecting stations (Bruce, 1971). The fact is probably the same in central Japan. A single species, Stoichactis haddoni, occurs in central Japan but it is very rare even in Kushimoto. Therefore the two common species of Parasicyonis are used as the host by the shrimps there.

$P$. ornatus seems to be the most common anemone-associated shrimp in Suruga Bay. It appears first in early August and has the ovigerous season from early October to early December, 1974. In 1976 it already appears in early April and the ovigerious females are collected in mid-June. There is no decrease of population during the period of observations. $H$. corallicola has been observed from early May to late January. Its ovigerous season is much longer than those of the other species. The ovigerious females were collected from late July to mid-November. P. brevicarpalis appears in early summer and its population gradually increases in number and in specimen size. Some of them establish pairs and then the ovigerous females occur from mid-September to late November. In December the large specimens disappear and the pair formation is broken. In $T$. amboinensis and $P$. holthuisi little data on the population structure is available.

$P$. brevicarpalis has its ovigerous season in autumn in central Japan. It is uncertain, however, whether its young specimens can tolerate the lowest temperature (about $13^{\circ} \mathrm{G}$ ) of the midwinter period, due to the lack of observations. Holthui (1952) reported the young specimens of this species were found among floating weeds on the high seas. Like many other tropical elements, this shrimp and probably the other two tropical shrimps, $P$. holthuisi and $T$. amboinensis, seem to be carried the Pacific coast of central Japan from southern waters by the warm Kuroshio Current during their planktonic or young stages. $H$. corallicora and $P$. ornatus, on the other hand, are rather different from the above-mentioned species in the progress of their acclimatization to central Japan and their distributional inclinations. Both species are very common on sea anemones in Suruga Bay and have no period of the population decrease during observations. They appear in spring and their ovigerous females are observed from late July to mid-November in the former species and from early October to early December in the latter species. The appearence of the ovigerous females, however, seems to vary in years. In $H$. corallicola the ovigerous females 
collected on June 23 are $5.23-6.5 \mathrm{~mm}$, while the ovigerous female on January 23 is smaller, only $4.0 \mathrm{~mm}$ in carapace length. In $P$. ornatus the ovigerous females are 4.0-5.25 $\mathrm{mm}$ in carapace length and no apparent size differences between the ovigerous females were observed in spring and autumn. Yasuda (1956) and Kosaka (1976) reported that some Japanese caridean shrimps have the long-term and shortterm generations in the Seto Inland Sea and Sendai Bay. Judging from the occurrences of the ovigerous females and population structure, $H$. corallicola and probably $P$. ornatus are thought to be well settled in central Japan and may also have long-term and short-term generations there.

\section{Acknowledgements}

The authors wish to express their cordial thanks to Dr. A. J. Bruce of the Heron Island Research Station, Queensland, Australia, for critical reading of the manuscript and for the useful seggestions and comments on the identification of the associated shrimps. Thanks are also due to Dr. H. Uchida of the Sabiura Marine Park Research Station, Kushimoto, Japan for the identification of the host sea anemones. The senior author is much indebted to Mr. Y. Oka of the Marine Science Museum, Tokai University and Messrs. K. Nakaishi, S. Nagai and K. Watanabe, the graduate students of the same university at that time, for their assistance in carrying out the present research.

\section{LITERATURE CITED}

Barnard, K.H., 1950. Descriptive catalogue of South African Decapod Crustacea. Ann. S. Afr. Mus., 38: 1-837, figs. 1-154.

Borradaile, L.B., 1917. On the Pontoniinae. The Percy Sladen Trust Expedition to the Indian Ocean, in 1905, under the leadership of Mr. J. Stanley Gardiner. Trans. Linn. Soc. Lond. Zool., (2) $17: 323-396$, pls. 52-57.

Bruce, A.J., 1969. Preliminary descriptions of sixteen new species of the genus Periclimenes Costa, 1844 (Grustacea, Decapoda Natantia, Pontoniinae). Zool. Meded., 43 (20) : 253-278.

Bruce, A.J., 1970. Notes on some Indo-Pacific Pontoniinae. XV. Hamopontonia corallicola gen. nov., sp. nov, a new pontoniid shrimp from Hong Kong. Crustaceana, 18: 37-48, figs. 1-4.

Bruce, A.J., 1971. Pontoniid shrimps from the ninth cruise of R/V Anton Bruun, IIOE, 1964: I. Palaemonella Dana and Periclimenes Costa. Smithsonian Cont. Zool., (82): 1-13, fig. 1.

Bruce, A.J., 1972. An association between a pontoniinid shrimp and a rhizostomatous scyphozoan. Crustaceana 23: 300-302.

Bruce, A.J., 1975. Coral reef shrimps and their colour patterns. Endeavour, 34: 23-27, figs. 1-16.

Bruce, A.J., 1976. Shrimps and prawns of coral reefs, with special reference to commensalism. Biology and Geology of Coral Reefs, III (Biol. 2): 37-94, figs. 1-21.

Bruce, A.J., 1976a. A report on some pontoniinid shrimps collected from the Seychelle Islands by the F.R.V. Manihine, 1972, with a review of the Seychelles pontoniinid shrimp fauna. Zool. J. Linn. Soc., 59: 89-153, figs. 1-30.

Chace, F.A., Jr., 1972. The shrimps of the Smithsonian-Bredin Caribbean Expeditions with a summary of the West Indian shallow-water species (Crustacea: Decapoda: Natantia). Smithsonian Cont. Zool., (98): 1-179, figs. 1-61.

Coutière, H., 1898. Notes sur la faune des récifs madréporiques de Djibouti. Bull. Mus. Hist. nat. Paris, 4 : 195-198. 
Gravely, F.H., 1927. Orders Decapoda (except Paguridea) and Stomatopoda. The littoral fauna of Krusadai Island in the Gulf of Manaar with appendices on the vertebrates and plants. Bull. Madras Govt. Mus., n. ser. (1): 135-155.

Hirata, H., Nakasone, Y. and S. Shokita, 1973. Shells, crabs and shrimps from Okinawa. Fudokisha, Co. Ltd. 144 p. with many figs. (in Japanese).

Holthuis, L.B., 1947. The Decapoda of the Siboga Expedition. Part IX. The Hippolytidae and Rhynchocinetidae collected by the Siboga and Snellius Expeditions with remarks on other species. Siboga Exped. monogr. $39 \mathrm{a}^{8}: 1-100$, figs. 1-15.

Holthuis, L.B., 1952. The Decapoda of the Siboga Expedition. Part XI. The Palaemonidae collected by the Siboga and Snellius expeditions with remarks on other species. II. Subfamily Pontoniinae. Siboga Exped. monogr. $39 \mathrm{a}^{10}$ : 1-252, figs. 1-110, 1 tab.

Holthuis, L.B. and I. Eibl-Eibesfeldt, 1964. A new species of the genus Periclimenes from Bermuda (Crustacea, Decapoda, Palaemonidae). Senk. biol., 45: 185-192, figs. 1-4.

Johnson, D.S., 1960. A synopsis of the decapod Caridea and Stenopodidea of Singapore with notes on their distribution and a key to the genera of Caridea occurring in Malayan waters. Bull. Nat. Mus., Singapore, 36: 44-79, 1 pl.

Kemp, S., 1916. Further notes on Hippolytidae. Notes on Crustacea Decapoda in the Indian Museum. VII. Rec. Ind. Mus., 12: 385-405, figs. 1-5, pl. 36 .

Kemp, S., 1922. Pontoniinae. Notes on Crustacea Decapoda in the Indian Museum. XV. Rec. Ind. Mus., 24: 113-288, figs. 1-105, pls. 3-9.

Kosaka, M., 1976. Ecological note on leptochelan shrimp, Leptochela aculeocaudata Paulson, in Sendai Bay. J. Fac. Mar. Sci. Technol. Tokai Univ., (9): 47-52 (in Japanese with English abstract).

Kubo, I., 1940. Pontoniinae. Studies on Japanese palaemonoid shrimps II. J. Imp. Fish Inst. Tokyo, 34: 31-75, figs. 1-36.

Limbaugh, C., Pederson, H., and F.A. Chace, Jr., 1961. Shrimps that clean fishes. Bull. mar. Sci. Gulf Carribean, 11:237-257, figs. 1-9.

McCulloch, A.R. and F.A. McNeill, 1923. Notes on Australian Decapoda. Rec. Aust. Mus., 14: 49-59, figs. 1-2, pls. 9-11.

Mahnken, G., 1972. Observations on cleaner shrimps of the genus Periclimenes. Results of the Tektite Program. Bull. Nat. Hist. Mus., Los Angeles County, 14: 71-83, figs. 39-44, tables 3-5.

De Man, J.G., 1888. Bericht über die von Herrn Dr. J. Brock im indischen Archipel gesammelten Decapoden und Stomatopoden. Arch. Naturgesch., 53 (1): 215-600, pls. 7-22a.

Miyake, S., 1975. Macrura and Anomura. In Utinomi, H. (comp.), Aquatic invertebrates, Gakken Chukosei Zukan, no. 9 (in Japanese).

Miyake, S. and T. Fujino, 1968. Pontoniid shrimps from the Palau Islands (Crustacea, Decapoda, Palaemonidae). J. Fac. Agr. Kyushu Univ., 14: 399-431, figs. 1-8.

Miyake, S. and K. Hayashi, 1966. Some hippolytid shrimps living in coral reefs of the West Pacific. J. Fac. Agr. Kyushu Univ., 14: 143-160, figs. 1-10.

Monod, T., 1969. Sur quatre crevettes de Noumea (Nouvelle-Caledonie). Cah. Pac., (13): 191222, figs. 1-73.

Nayer, S.G., 1947. The newly hatched larva of Periclimenes (Ancylocaris) brevicarpalis (Schenkel). Proc. Ind. Acad. Sci., (B) 26: 168-176, figs. 1-10.

Nobili, G., 1906. Crustaces Decapodes et Stomatopodes. Mission J. Bonnier et Ch. Perez (Golfe Persique, 1901). Bull. Sci. France Belg. 40: 13-159, figs. 1-3, pls. 2-7.

Patton, W.K., 1966. Decapod crustacea commensal with Queensland branching corals. Crustaceana, 10: 271-295, figs. 1-3.

Saville-Kent, W., 1893. The Great Barrier Reef of Australia; its products and potentialities, i-xvii, $1-387$.

Schenkel, E., 1902. Beitrag zur Kenntnis der Dekapodenfauna von Celebes. Verh. naturf. Ges. Basel, 13: 485-585, pls. 7-13.

Stephenson, T.A., Stephenson, A., Tandy, G. and M. Spender, 1931. The structure and ecology of Low Isles and other reefs. Sci. Rep. Great Barrier Reef Exped., 3: 17-112.

Suzuki, K., Kobayashi, K., Abe, H. and T. Fukuda, 1972. Outline of undersea scope and shallowwater fauna of the coast of Minamiizu-machi, southernmost part of Izu Peninsula. Rep. for the Survey of Marine Park in Shizuoka Prefecture: 5-17, figs., 1-2 (in Japanese). 
Suzuki, K. and M. Takeda, 1974. On a parthenopid crab, Zebrida adamsii on the sea urchins from Suruga Bay, with a special reference to their parasitic relations. Bull. Natn. Sci. Mus., 17: 287296 , figs. 1-4, pl. 1 .

Uchida, H., Okamoto, K. and T. Fukuda, 1975. Some observations on the symbiosis between anemonefishes and sea-anemones in Japan. Bull. Mar. Park Res. Station, 1: 31-46, pls. 1-3.

Yasuda, J., 1956. Biological study on the shrimps resource in the Bay-II. Naikai Reg. Fish. Res. Lab., (9) : 1-81, figs. 1-46 (in Japanese). 
Plate I. Anemone-associated shrimp, Hamopontonia corallicola Bruce, showing colour variation, 1 , juvenile, 2 , mature male, 3 , ovigerous female.

Plate II. Shrimps associated with sea anemone, Parasicyonis actinostroides (Wassilieff), in an aquarium. 1, a pair of Periclimenes brevicarpalis (Schenkel); left, mature male, right, ovigerous female. 2, female of Periclimenes ornatus Bruce. 
Publ. Seto Mar. Biol. Lab., XXIV (1/3), 1977.

PLATE I
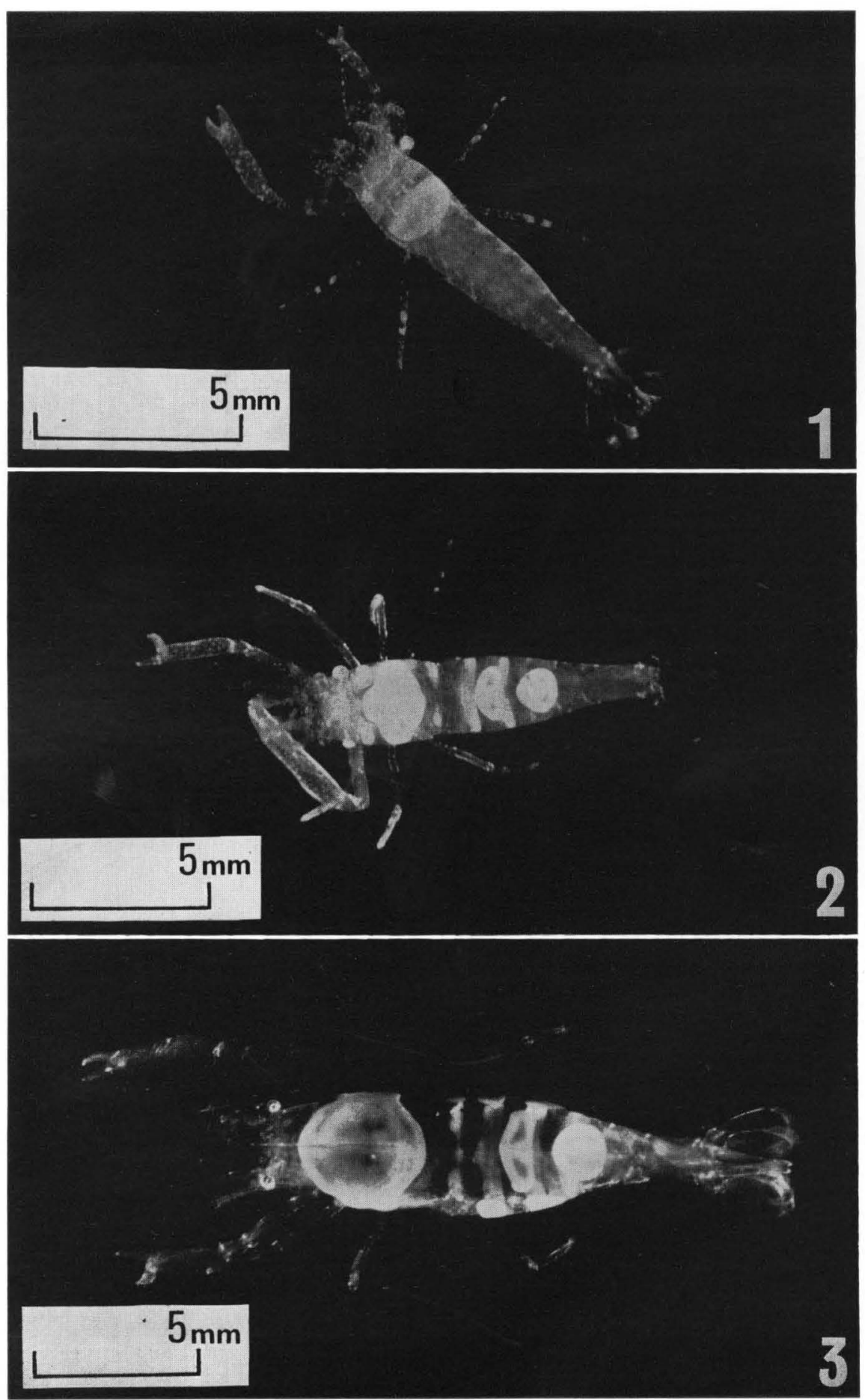

K. Suzuki \& K. Hayashi: Caridean Shrimps Associated with Sea Anemones 
Publ. Seto Mar. Biol. Lab., XXIV (1/3), 1977.

PLATE II
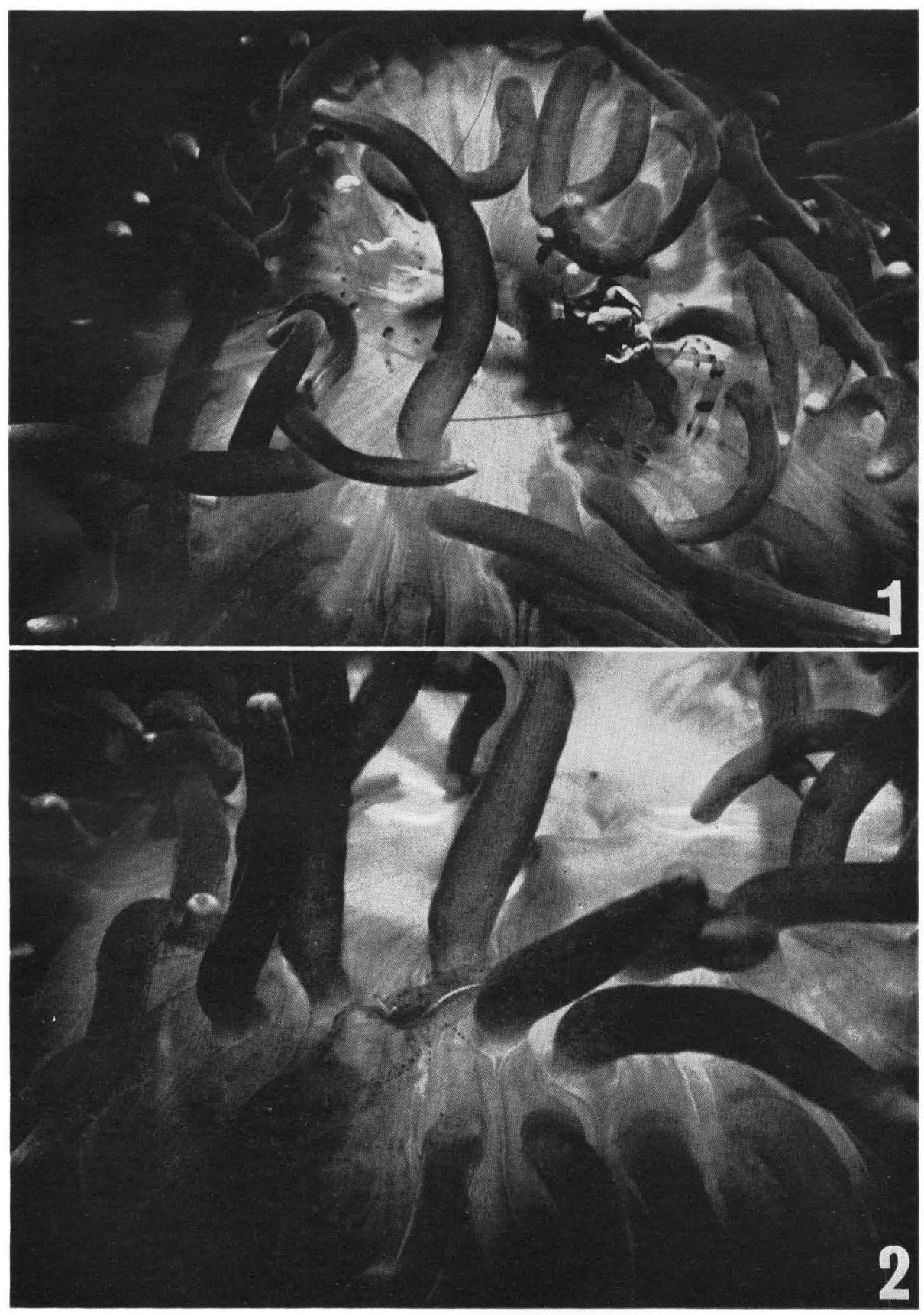

K. Suzuki \& K. Hayashi: Caridean Shrimps Associated with Sea Anemones 